\author{
Rucha Lakhne, Rajnish Gupta and \\ Gupta RS \\ Department of Zoology, Reproductive Physiology \\ Section, Centre for Advanced Studies, University of \\ Rajasthan, Jaipur - 302 004, India \\ Dates: Received: 12 August, 2015; Accepted: 31 \\ August, 2015; Published: 03 September, 2015 \\ *Corresponding author: Dr. RS Gupta, \\ Reproductive Physiology Section, Department of \\ Zoology, University of Rajasthan, Jaipur - 302004 \\ India, Tel: +91-+91-9414279845; Fax: +91-141- \\ 2701137; E-mail: gupta_rs@hotmail.com \\ www.peertechz.com \\ Keywords: Blood cholesterol; Cardiovascular \\ disorder; Medicinal Plants; Hypercholesterolemia \\ ISSN: 2640-7582
}

\author{
Review Article
}

\section{Active Phytoconstituents for Controlling Hypercholesterolemia: A Review}

\section{Abbreviations}

LDL: Low Density Lipoproteins; HDL: High Density Lipoproteins; VLDL: Very Low Density Lipoproteins; G: Triglycerides; TC: Total Cholesterol; NCEP: National Cholesterol Education Program; dL: deciliter; ABG: Aged Black Garlic; LPO: Lipid Peroxidase; HCD: Hypercholesterolemic Diet; DPPH: 1,1-Diphenyl-2- picrylhydrazyl; FRAP: Ferric-Reducing Antioxidant Power; TBARS: Thiobarbituric Acid Reactive Substances; HFD: High-Fat Diet; SGOT: Serum Glutamic Oxaloacetic Transaminase; SGPT: Serum Glutamic Pyruvic Transaminase; CMFJ: Cucumis Belo Fruit Juice; SG: Sesbania Grandiflora; AI: Atherogenic Index.

\section{Introduction}

Hypercholesterolemia is a disorder of lipid metabolism manifested by elevation of plasma concentrations of the various lipid and lipoprotein fractions, which is the key risk factor for cardiovascular disorders [1] and has been reported as the most common cause of death in developed as well as developing nations $[2,3]$.

The modern lifestyle, with a high fat diet and little physical activity, significantly contributes to hypercholesterolemia and cardiovascular diseases [4]. The abnormal cholesterol levels are the result of an unhealthy lifestyle including taking high-fat diet and other lifestyle factors like being overweight, smoking, heavy alcohol use and lack of exercise. Other factors include diabetes, kidney disease, pregnancy, and an underactive thyroid gland [5]. Other illnesses that may elevate cholesterol levels include polycystic ovary syndrome and kidney disease. The higher levels of female hormones like oestrogen, have been noted to increase or change cholesterol levels. In addition, drugs like diuretics, beta-blockers and medicines used to treat depression have also been reported to raise cholesterol levels [6]. Another modifying factors in the development and progression of hyperlipidemia are age and gender. It has been shown that cholesterol levels rise as the person gets older [7-9].
High levels of low-density lipoprotein (LDL) cholesterol accumulate in the extracellular sub endothelial space of arteries; these are highly atherogenic and toxic to vascular cells, leading to atherosclerosis, hypertension, obesity, diabetes, and functional depression in organs such as the liver, heart, and kidneys [10]. Clinical trials have shown that lowering lipids reduces the morbidity and mortality associated with cardiovascular complications [11].

\section{Classification of lipid concentrations}

The lipids can be classified as TC, triglycerides, LDL, HDL and very low density lipoprotein (VLDL) cholesterol.

Total cholesterol: According to guidelines of National Cholesterol Education Program (NCEP), TC concentrations below $200 \mathrm{mg} / \mathrm{dL}$ have been regarded as desirable, whereas, concentrations greater than $240 \mathrm{mg} / \mathrm{dL}$ are referred to as hyperlipidemic. However, epidemiological evidence suggests that the risk of cardiac events decreases as TC levels fall approximately to $150 \mathrm{mg} / \mathrm{dL}$. Moreover, TC should be less than $180 \mathrm{mg} / \mathrm{dL}$ for children.

Triglyceride: The excess calories, alcohol or sugar in the body get converted into triglycerides and stored in fat cells throughout the body. The triglyceride concentration less than $150 \mathrm{mg} / \mathrm{dL}$ is regarded as normal, whereas, concentrations of $200-499 \mathrm{mg} / \mathrm{dL}$ are considered as high.

LDL cholesterol: LDL is commonly known as the bad cholesterol, which is produced by the liver and carry cholesterol and other lipids from the liver to different areas of the body like muscles, tissues, organs and heart. The high levels of LDL indicate much more cholesterol in the blood stream than necessary and hence, increase the risk of heart disease. According to NCEP guidelines, LDL cholesterol concentrations below $100 \mathrm{mg} / \mathrm{dL}$ are considered optimal, whereas concentrations in the range of $160-189 \mathrm{mg} / \mathrm{dL}$ are considered to the higher side. However, increasing evidence supports that normal human LDL cholesterol concentration can be as low as 50 to $70 \mathrm{mg} /$ dL. 
HDL cholesterol: HDL is commonly referred to as the good cholesterol, which is produced by the liver to carry cholesterol and other lipids from tissues back to the liver for degradation. High levels of HDL cholesterol have been considered as a good indicator of a healthy heart. The concentrations of $60 \mathrm{mg} / \mathrm{dL}$ or higher have been considered as optimal. However, HDL is often interpreted in the context of TC and LDL concentrations, and hence may be regarded as less significant when LDL is low.

VLDL cholesterol: VLDL is similar to LDL cholesterol in the sense that it contains mostly fat and not much protein. They are formed by a combination of cholesterol and triglycerides. Moreover, VLDLs are heavier than LDL, and are also associated with atherosclerosis and heart disease.

\section{Mechanism of lipid transport}

Lipids are insoluble in water. Hence, they are transported around the body as lipoproteins. Lipids originate from two sources: endogenous lipids, synthesized in the liver, and exogenous lipids, ingested and processed in the intestine. Approximately $7 \%$ of body's cholesterol circulates in plasma in the form of low density lipoproteins (LDL). The level of plasma cholesterol is influenced by its synthesis and catabolism in which liver plays a crucial role.

\section{Causes of hyperlipidemia}

The main cause of hyperlipidemia includes changes in lifestyle habits in which risk factor is mainly poor diet i.e. with a fat intake greater than 40 percent of total calories, saturated fat intake greater than 10 percent of total calories; and cholesterol intake greater than 300 milligrams per day or treatable medical conditions. The abnormal cholesterol levels are the result of an unhealthy lifestyle including taking high-fat diet and other lifestyle factors like being overweight, smoking heavy alcohol use and lack of exercise. Other factors include diabetes, kidney disease, pregnancy, and an underactive thyroid gland.

\section{Plants and plant products}

The main aim of treatment in patients with hypercholesterolemia is to reduce the risk of developing ischemic heart disease or the occurrence of further cardiovascular or cerebrovascular disease [12]. The consumption of synthetic drugs leads to hyperuricemia, diarrhoea, nausea, myositis, gastric irritation, flushing, dry skin and abnormal liver function.

The medicinal plants play a major role in hypocholesterolemic activity [13]. Herbal medicines have been main source of primary healthcare in all over the world. Chemical principles from natural sources have become much simpler and have contributed significantly to the development of new drugs from medicinal plants [14].

\section{Review of literature}

Allium sativum: Animals were fed with two types of diets: a normal diet and high-fat diet and were orally administered with A. sativum Body weight, lipid parameter, antioxidant enzymes activity and LPO in serum and liver were investigated. Extract doses significantly lowered body weight, improved lipid profile and decreased serum
LPO level relative to the control. These results suggest $A$. sativum administration improves body weight gain, alteration in lipid profiles and antioxidant defense system [15-17] (Figure 1).

Allium porrum: Animals were fed with two types of diet and administered with $A$. porrum extract. Blood samples were analyzed for plasma cholesterol, triglycerides, LDL, VLDL and HDL cholesterol. Thus the changes in distribution of cholesterol decreased significantly in all groups treated with A. porrum extract compared to hypercholesterolemic group. These findings indicate that this plant may be useful for treating hypercholesterolemia [18] (Figure 2).

Avena sativa: The animals were fed with the experimental diet. It was found that oat oil lowered plasma total, LDL cholesterol, liver total, free cholesterol, cholesterol ester and TG. Even, the faecal weight, total lipids and bile acid concentration increased in oat oil. It was concluded that oat oil improves hypercholesterolemia in rats fed with HCD by enhancing excretions of faecal lipids and bile acids [19-21] (Figure 3).

Bacopa monnier: The plant material of B. monniera was extracted and was fed to the hypercholesterolemic rats. Biochemical and histological changes were analyzed and found decrease in the levels of Total cholesterol, TG, plasma lipid, LDL, VLDL, atherogenic index, LDL/HDL ratio and Total cholesterol/HDL ratio but increase in the levels of HDL compared to HCD fed rats. These results suggest that

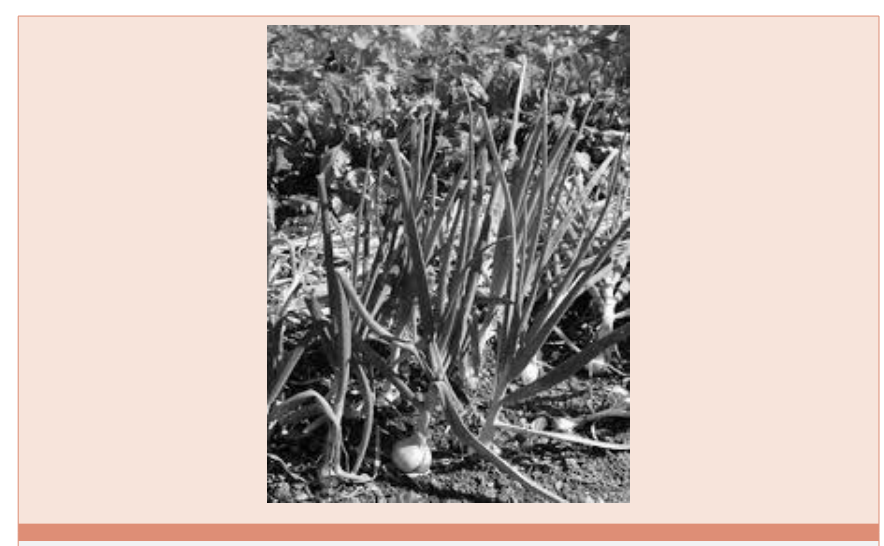

Figure 1: Allium sativum.

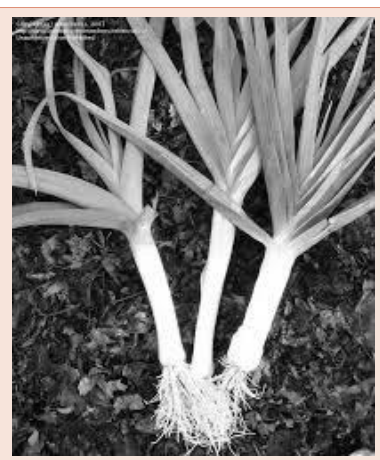

Figure 2: Allium porrum. 


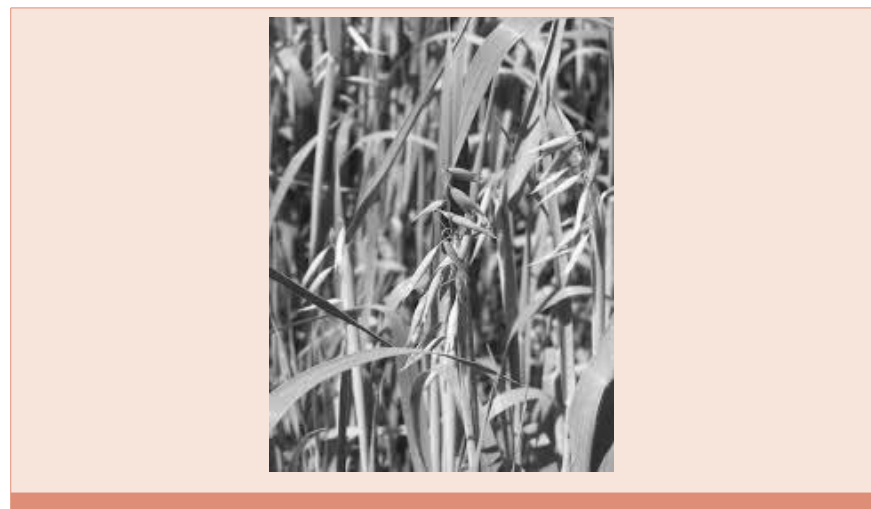

Figure 3: Avena sativa.

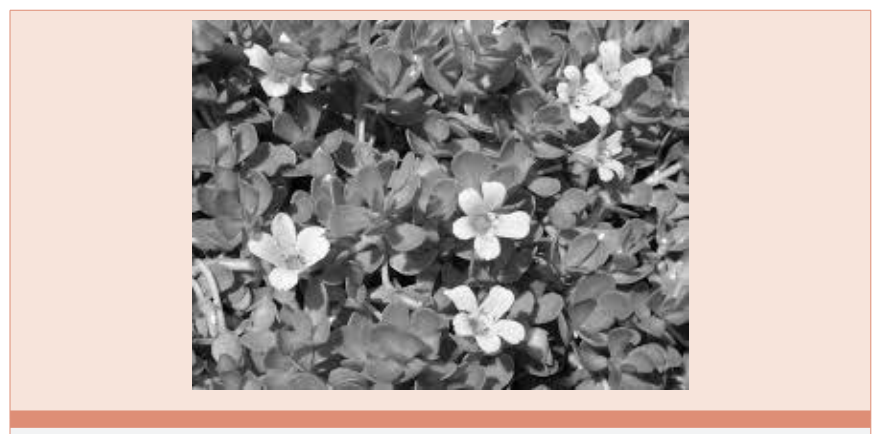

Figure 4: Bacopa monniera.

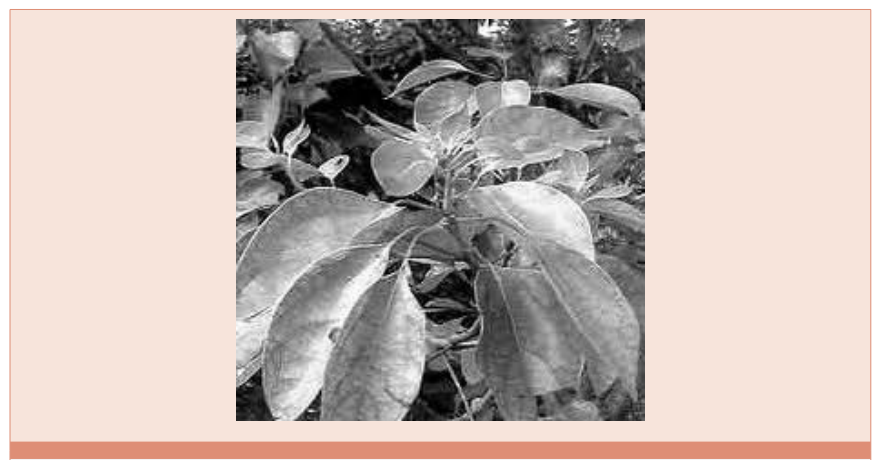

Figure 5: Cinnamomum tamala.

this plant protects against biochemical changes and aortic pathology in hypercholesterolemic rats [22,23] (Figure 4).

Cinnamomum tamala: The study was to investigate the hypolipidemic effect of C. tamala leaves extract in high cholesterol diet induced hyperlipidemia. These resulted in prevention of rise in serum levels of total cholesterol, TG, LDL, VLDL and atherogenic index whereas increase in level of HDL [24,25] (Figure 5).

Citrus mitis: The rats fed with high cholesterol diet were examined with extract of C. mitis. The supplementation of C. mitis extract respectively reduced plasma total cholesterol, LDL and TG levels and increased level of HDL and suggested that $C$. mitis extract possesses lipid lowering and antioxidative effect [26] (Figure 6).
Cucumis melo: C. melo fruit juice (CMFJ) (2.5, 5.0 and 7.5 $\mathrm{ml} / \mathrm{kg}$ p.o.) was administered to high-cholesterol diet induced hyperlipidemia in rats. Treatment with $7.5 \mathrm{ml} / \mathrm{kg}$ CMFJ significantly reduced serum total cholesterol (TC), TG, LDL level, atherogenic index and increased the serum HDL levels when compared to control [27] (Figure 7).

Cyamopsis tetragonoloba: Male Wistar rats were maintained for 8 weeks either on high $(0.5 \%)$ cholesterol diet or basal control diet. Significant anti-hypercholesterolemic effect was seen in cluster bean fed animals at 12.5 and 25 per cent levels and found decrease in serum LDL associated fraction and increase in HDL associated cholesterol fraction. Hepatic lipid profile showed a significant decrease in both cholesterol and triglycerides [28] (Figure 8).

Emblica officinalis: 5 groups of 6 animals in each received normal saline, E. officinalis powder, high fat diet, High fat diet plus E. officinalis powder both and Atorvastatin respectively for 8 weeks. Blood samples of the animals were estimated for the lipid profile and effects of test drug studied by comparing levels of Total Cholesterol, TG, HDL, LDL, and Atherogenic index. Fruit of Amla showed significant anti-hyperlipidemic, hypolipidemic, and anti-atherogenic effect [29] (Figure 9).

Macrotyloma uniflorum: Animals were fed with experimental high-fat diets (HFD) The consumption of ethanol and water extract of experimental plant for 5 weeks caused the decrease in total cholesterol (TC), TG, LDL, VLDL, SGOT and SGPT and increase in HDL and the rat group fed with HFD has higher serum TC, TG, LDL, VLDL, SGOT, SGPT, and lower HDL. Faecal excretion of cholesterol in the

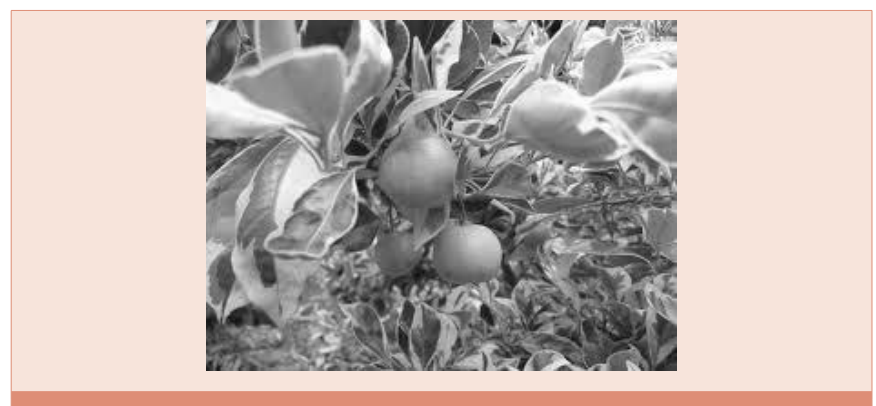

Figure 6: Citrus mitis.

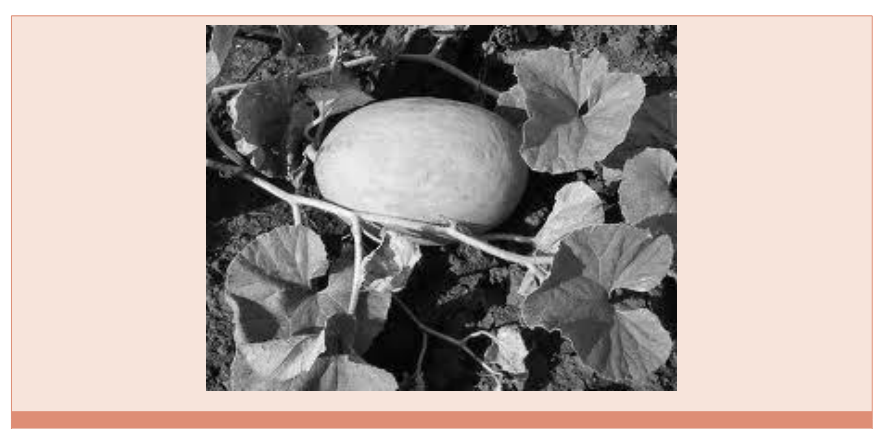

Figure 7: Citrus mitis. 


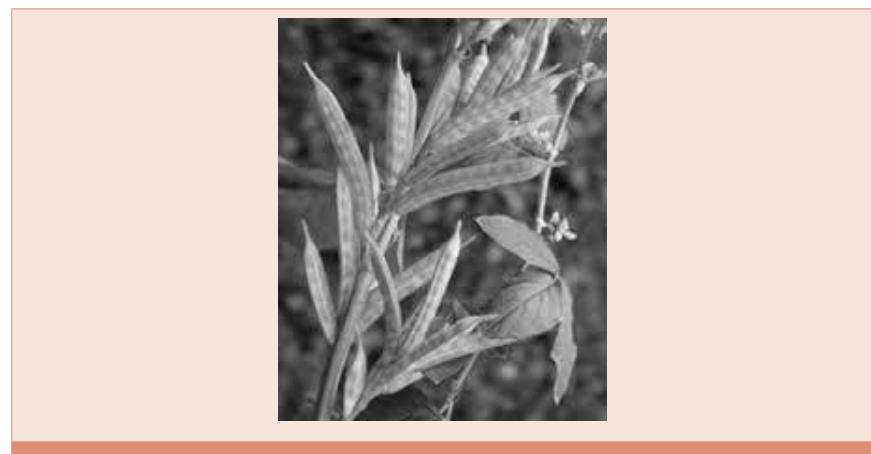

Figure 8: Cyamopsis tetragonoloba.

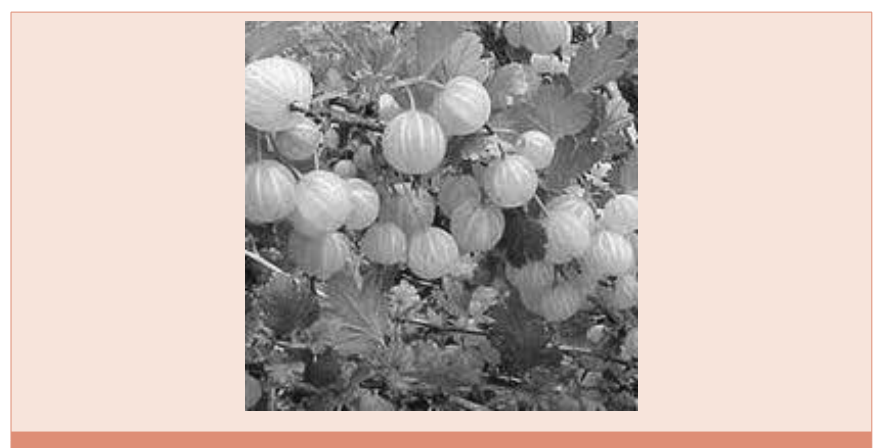

Figure 9: Emblica officinalis.

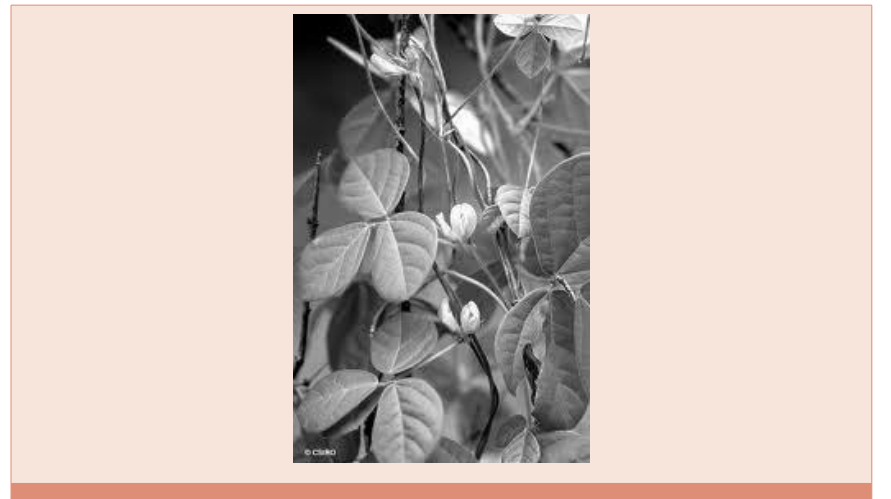

Figure 10: Macrotyloma uniflorum.

ethanol extract-treated groups was significantly higher than those treated with water extract. Body weight in the water extract treated groups was significantly lower than that in the ethanol extract-treated groups [30] (Figure 10).

Mimosa pudica: The hypolipidemic activity of M. pudica extract was studied on high fat diet induced models of hyperlipidemia in rats. Ethanol extract showed significant hypolipidemic effect by lowering the serum levels of biochemical parameters such as significant reduction in the level of serum Cholesterol, TG, LDL, VLDL and increase in HDL level which was similar to the standard drug Lovastatin [31] (Figure 11).

Moringa oleifera: Albino Wistar rats received cholesterol (400mg/kg b.wt. in $5 \mathrm{ml}$ coconut oil p.o) and were tested orally at the dose of 150, 300 and $600 \mathrm{mg} / \mathrm{kg}$ body weight. The extract $(300 \mathrm{mg} / \mathrm{kg}$ $\& 600 \mathrm{mg} / \mathrm{kg}$ ) showed significant reduction in total serum cholesterol and lipid levels compared to vehicle control group. The study proved that ethanolic stem bark extracts of $M$. oleifera shows significant anticholesteremic and antilipidemic activity [32] (Figure 12).

Nasturtium officinale: Intragastric administration of $N$. officinale hydroalcoholic extract (500 mg/kg b.wt. per day) to groups of hypercholesterolemic rats for 10 days lowered their serum TC, TG and LDL-C by $34.2,30.1$, and $52.9 \%$, respectively, while raised the serum HDL-C level by $27.0 \%$ after 10 days of treatments [33] (Figure 13).

Phyllanthus reticulates: Experimental rats were divided into different groups: normal, hypercholesterolemic control and $P$. reticulatus treated (250 and $500 \mathrm{mg} / \mathrm{kg}$ b.wt. doses for 45 days). The aqueous extract of $P$. reticulatus $(250 \mathrm{mg}$ and $500 \mathrm{mg} / \mathrm{kg}$ ) produced

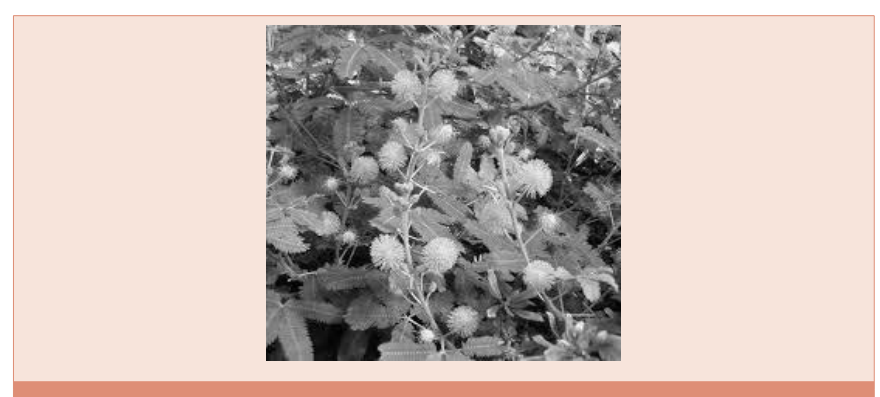

Figure 11: Mimosa pudica.

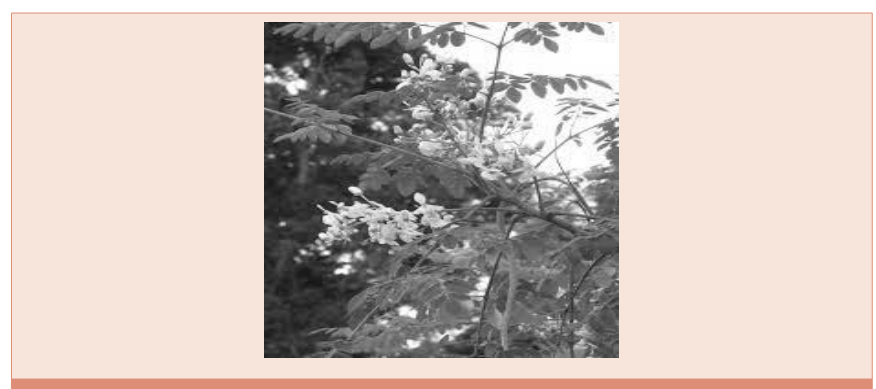

Figure 12: Moringa oleifera.

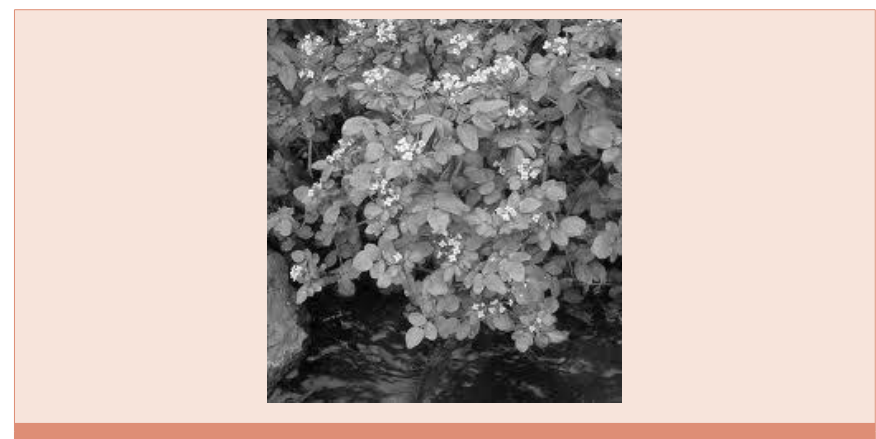

Figure 13: Nasturtium officinale. 


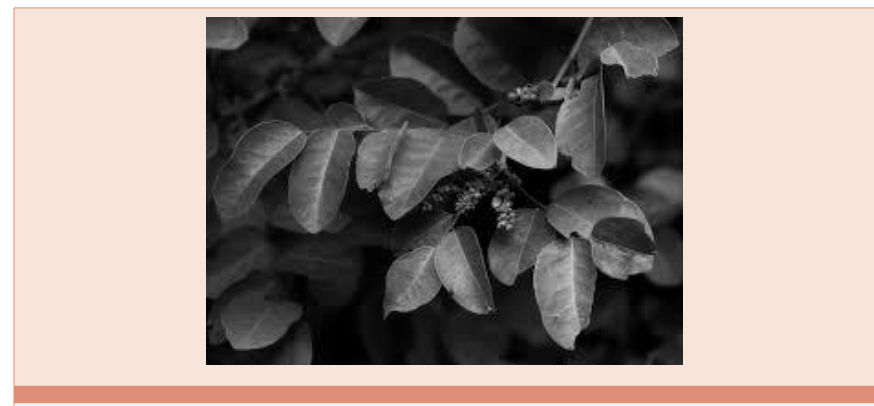

Figure 14: Phyllanthus reticulatus.

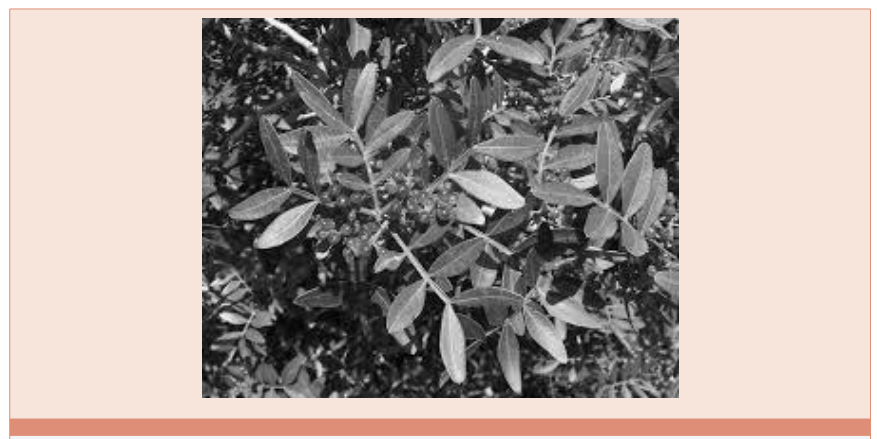

Figure 15: Pistacia lentiscus.

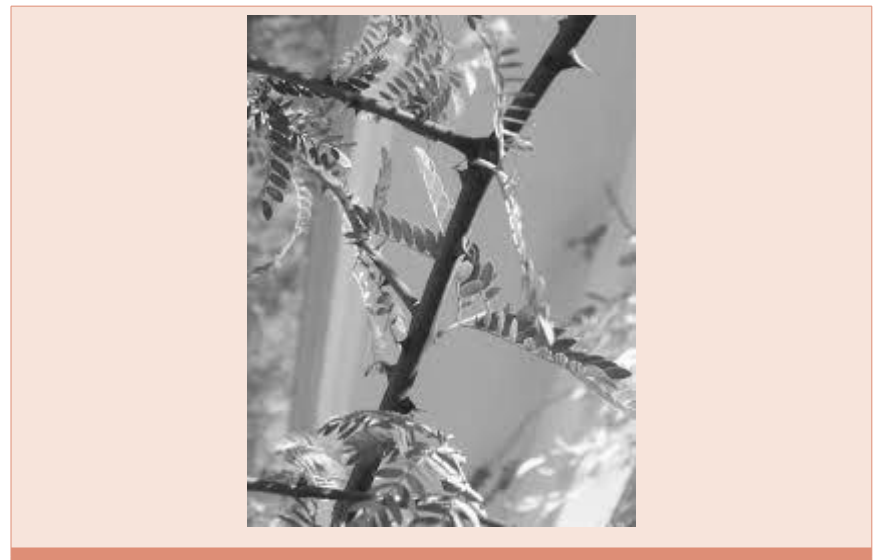

Figure 16: Prosopis cineraria.

significant reduction in TG, VLDL, total cholesterol (TC), LDL and oxidative stress (protein carbonyl) while increase in HDL [34] (Figure $14)$.

Pistacia lentiscus: Sprague-Dawley rats were divided into 9 groups (20/group): control; hypercholesterolemic; hypercholesterolemic treated with: hypocholesterolemic drug, pistachio, almonds, mixture of pistachio and almonds; normal rats treated with pistachio, almonds, mixture of pistachio and almonds. The experiment lasted 6 weeks after treatment. The results of the study showed that diet supplemented with pistachio and/or almond induced significant decrease in TC and LDL-C, VLDL TG and phospholipids level, while HDL-C levels were unchanged compared to hypercholesterolemic group [35] (Figure 15).
Prosopis cineraria: Hypercholesterolemia was induced in rabbits orally with high fat diet and cholesterol powder $(500 \mathrm{mg} / \mathrm{kg}$ b.wt/ day). The treatment of $P$. cineraria bark extract reduced lipid profile parameters i.e. total cholesterol up to $91.7 \%$, LDL cholesterol 93\%, triglyceride 59\% and VLDL- cholesterol 60\% [36] (Figure 16).

Rhus coriaria $L$ : The hypolipidemic effects of aqueous methanol extract sumac ( $R$. coriaria $L$.) fruits in high cholesterol diet (HCD)fed rats was investigated. There was a significant increase in the levels of total cholesterol (TC) and triglycerides (TG) and concluded that sumac fruit extract minimized the lipid abnormalities and abnormal biochemical changes induced in HCD fed rats [37] (Figure 17).

Sesbania grandiflora: The aqueous extract of leaves of $S$. grandiflora (SG) was administered a dose of $200 \mu \mathrm{g} / \mathrm{kg}$ (p.o) to the triton induced hyperlipidemic rats. SG shows a significant decrease in the levels of serum cholesterol, phospholipids, triglyceride, LDL, VLDL and significant increase in the level of serum HDL at the dose of $200 \mu \mathrm{g} / \mathrm{kg}$ (p.o.) [38] (Figure 18).

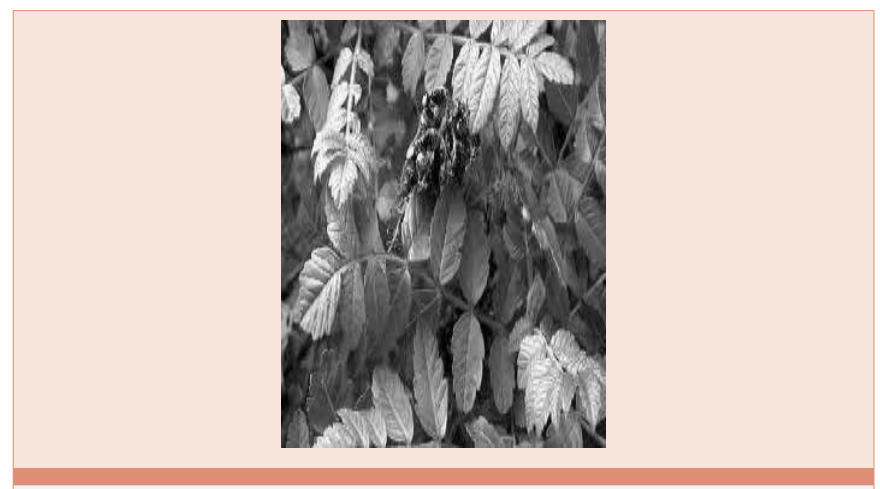

Figure 17: Rhus coriaria.

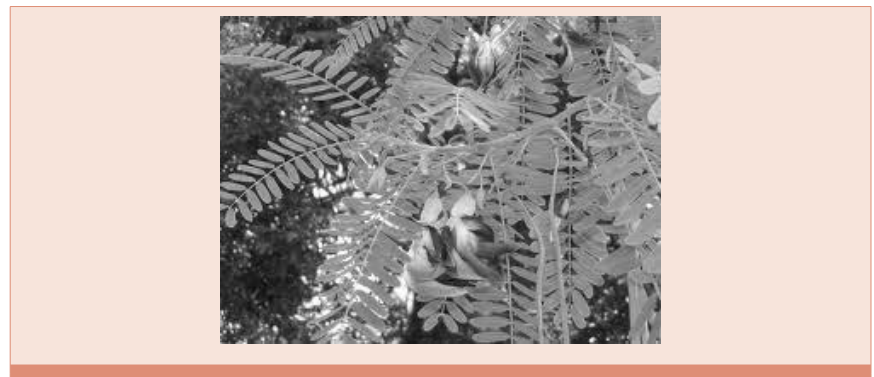

Figure 18: Sesbania grandiflora.

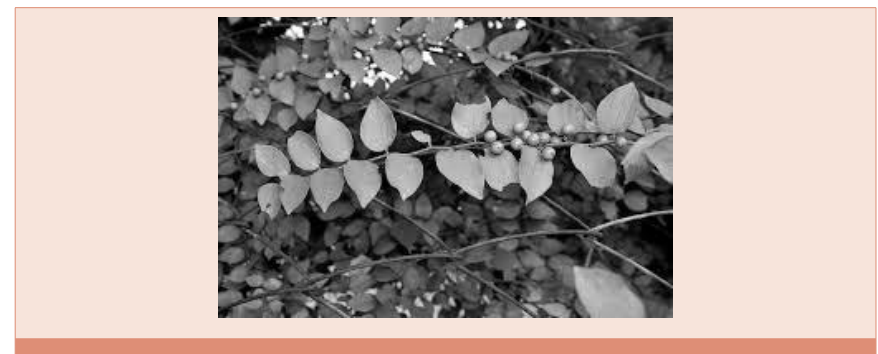

Figure 19: Solanum macrocarpon. 


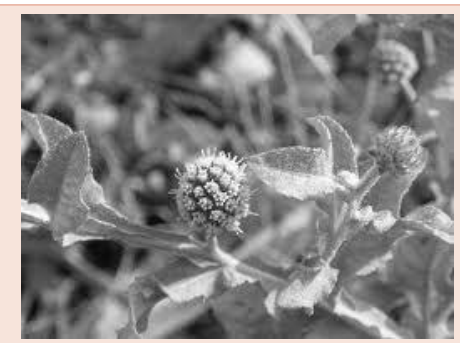

Figure 20: Sphaeranthus indicus

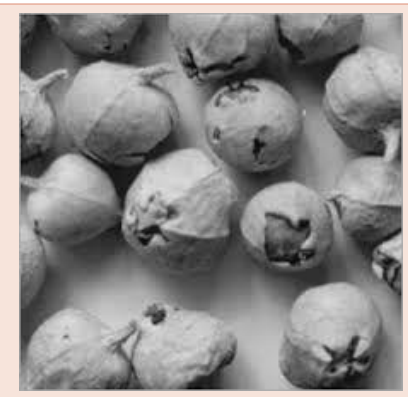

Figure 21: Withania coagulans.

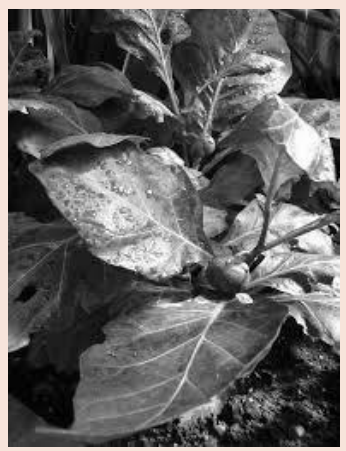

Figure 22: Ziziphus oenoplia.
Solanum macrocarpon: The leaves and fruits of $S$. macrocarpon were administered (p.o.) for 7 days to Wistar rats at doses of 400 and $800 \mathrm{mg} / \mathrm{kg}$ of body weight and Atorvastatin was used as a reference drug. Administration of $S$. macrocarpon resulted in a significant decrease in total cholesterol, LDL, VLDL and triglycerides and increase in HDL was observed in the treated groups [39] (Figure 19).

Sphaeranthus indicus: Alcoholic extract of S. indicus Linn. Flower was tested on hyperlipidemic male albino rats for 8 days. $500 \mathrm{mg} / \mathrm{kg} /$ day drug significantly decreased the level of TC, and LDL as compared to control with increased HDL and it also reduced atherogenic index [40] (Figure 20).

Withania coagulans: An aqueous extract of fruits of $W$. coagulans $(\mathrm{g} / \mathrm{kg}$; p.o.) were administered to high fat diet induced hyperlipidemic rats for 7 weeks; this significantly reduced the elevated serum cholesterol, triglycerides and lipoprotein levels [41] (Figure 21).

Ziziphus oenoplia: Ethanolic extract of Z. oenoplia leaf was administered to the Wistar albino rats at two dose levels $(250 \mathrm{mg} / \mathrm{kg}$ and $500 \mathrm{mg} / \mathrm{kg}$ ) which showed significant hypolipidemic activity by reduction in the level of serum cholesterol, triglyceride, LDL, VLDL, $\mathrm{AI}, \mathrm{LDL}-\mathrm{C} / \mathrm{HDL}-\mathrm{C}$ ratio and increase in HDL level as compared to cholesterol control groups [42] (Figure 22).

\section{Conclusion}

Plant and plant products have been in attention since earlier days as an effective option to reduce body weight and body fat. This review reports the advantages of herbal drugs over the synthetic drugs. Major fraction of the plants listed above has been reported with anti-oxidative effect which may be important in the management of diseases accompanying with obesity like cardiovascular diseases. The need to discover anti- hypercholesterolemic drugs having better efficacy and lower adverse effect is still felt. The result of this review can be helpful for the drug industry to study on the components of these herbs and investigate further to find a component with higher efficacy. Further well-designed clinical trials are still needed to focus on safe and cost effective herbal products.

\section{Table 1:}

\begin{tabular}{|c|c|c|c|c|c|c|}
\hline $\begin{array}{l}\text { S. } \\
\text { No. }\end{array}$ & $\begin{array}{l}\text { Name of } \\
\text { plant }\end{array}$ & Family & Activity & $\begin{array}{l}\text { Animal } \\
\text { Model }\end{array}$ & Phytoconstituents isolated & References \\
\hline 1. & $\begin{array}{l}\text { Allium } \\
\text { sativum }\end{array}$ & Lilliceae & $\begin{array}{l}\text { Insecticidal, fungicidal, acaricidal, nematicidal, } \\
\text { bactericidal and cardiovascular effects }\end{array}$ & $\begin{array}{l}\text { Male } \\
\text { Sprague- } \\
\text { Dawley } \\
\text { rats }\end{array}$ & $\begin{array}{l}\text { Alliin, vitamin C, total phenol, total flavonoid } \\
\text { and free sugars. }\end{array}$ & Kim et al. [15] \\
\hline 2. & $\begin{array}{l}\text { Allium } \\
\text { porrum }\end{array}$ & Liliaceae & $\begin{array}{l}\text { Anti-inflammatory, anti-septic, anti-cholesterol, } \\
\text { anti-atherosclerosis, anti aphrodisiac effects, anti- } \\
\text { balsamic action, regulate intestinal function. }\end{array}$ & Rabbits & $\begin{array}{l}\text { Porrigenin } C \text {, agigenin, diosgenin, } \beta \text { - } \\
\text { chlorogenin and } 24 \text {-ethyl cholesta- (6-acyl)- } \\
\text { 3-O- } \beta \text {-D-glucoside }\end{array}$ & $\begin{array}{l}\text { Movahedian et } \\
\text { al. [18] }\end{array}$ \\
\hline 3. & Avena sativa & Poaceae & $\begin{array}{l}\text { Antioxidant, anti-nflammatory, } \\
\text { wound healing, immuno-modulatory, antidiabetic, } \\
\text { anticholesterolaemic }\end{array}$ & Rats & $\begin{array}{l}\text { Avenanthramides, gramine, flavonoids, } \\
\text { flavonolignans, triterpenoid saponins, } \\
\text { sterols and tocols. }\end{array}$ & Tong et al. [19] \\
\hline 4. & $\begin{array}{l}\text { Bacopa } \\
\text { monniera }\end{array}$ & Plantaginaceae & $\begin{array}{l}\text { Memory enhancement, antidepressant, anxiolytic, } \\
\text { Anticonvulsant antiparkinsonian, antioxidant, } \\
\text { gastrointestinal, endocrine ,antimicrobial, anti- } \\
\text { inflammatory, analgesic, cardiovascular and } \\
\text { smooth muscle relaxant effects. }\end{array}$ & Rats & $\begin{array}{l}\text { Alkaloid brahmine, nicotinine, herpestine, } \\
\text { bacosides A, triterpenoid, saponins, } \\
\text { saponins A, B and C, betulinic acid, } \\
\text { D-mannitol, stigmastanol, } \beta \text {-sitosterol, } \\
\text { stigmasterol and Pseudojujubogenin } \\
\text { glycoside. }\end{array}$ & $\begin{array}{l}\text { Kamesh and } \\
\text { Sumathi. [22] }\end{array}$ \\
\hline
\end{tabular}




\begin{tabular}{|c|c|c|c|c|c|c|}
\hline 5. & $\begin{array}{l}\text { Cinnamo- } \\
\text { mum tamala }\end{array}$ & Lauraceae & $\begin{array}{l}\text { Anti-inflammatory, antioxidant, antiulcer, } \\
\text { anticarcinogenic, antidiarrhoeal, antidiabetic }\end{array}$ & & $\begin{array}{l}\text { Reducing sugar, glycoside, tannins, steroid, } \\
\text { amino acid \&alkaloid. }\end{array}$ & $\begin{array}{l}\text { Dhulasavant } \\
\text { et al. [24] }\end{array}$ \\
\hline 6. & Citrus mitis & Rutaceae & $\begin{array}{l}\text { Anti-oxidant, anti-arcinogenic, } \\
\text { Anti-ulcer, anti-anxiety, anti- } \\
\text { Typhoid, anti-bacterial, larvicidal Anti-diabetic, anti- } \\
\text { fungal, anti-Inflammatory, anti-arthritic. }\end{array}$ & Rats & $\begin{array}{l}\text { D-limonene, citral, citonellal, Nootkaton, } \\
\text { sinesal, n-nonanal, n-decanal, n-dodecanal, } \\
\text { linalyl acetate, geranyl acetate, citronelyl } \\
\text { acetate and anthranil acid methyl ester. }\end{array}$ & $\begin{array}{l}\text { Zulkhairi } \\
\text { et al.[26] }\end{array}$ \\
\hline 7. & $\begin{array}{l}\text { Cucumis } \\
\text { melo }\end{array}$ & Cucurbitaceae & $\begin{array}{l}\text { Anti-inflammatory, anti-oxidant, Anti-diabetic, anti- } \\
\text { ulcer, anti-Microbial, hepato-protective, anti-cancer, } \\
\text { anti-helminthic and anti-fertility. }\end{array}$ & Rats & $\begin{array}{l}\text { Alkaloids, tannins, carbohydrates, proteins, } \\
\text { flavonoids, steroids, anthraquinones, } \\
\text { coumarin, glycosides, terpenoids } \\
\text { and phenolic acids }\end{array}$ & $\begin{array}{l}\text { Luhure } \\
\text { et al. [27] }\end{array}$ \\
\hline 8. & $\begin{array}{l}\text { Cyamopsis } \\
\text { tetragonolo- } \\
\text { ba }\end{array}$ & Fabaceae & $\begin{array}{l}\text { Anti-secretory, hypolipidemic } \\
\text { Antihyperglycemic, anticancer, antimycoplasmal. }\end{array}$ & $\begin{array}{l}\text { Male } \\
\text { Wistar } \\
\text { Rats }\end{array}$ & $\begin{array}{l}\text { Gallotannins, gallic acid, gallic Acid } \\
\text { derivatives, myricetin-7-glucoside-3- } \\
\text { glycoside, chlorogenic acid, ellegic acid, } \\
\text { 2,3,4-trihydroxybenzoic acid, texasin-7- } \\
\text { O-glucoside and p-coumaryl quinic acid, } \\
\text { campesterol, avenasterol, stigmasterol, } \\
\text { sitosterol and traces of Delta-7-avenasterol, } \\
\text { stigmast-7-enol, Brassicasterol and } \\
\text { cholesterol }\end{array}$ & $\begin{array}{l}\text { Pande et al., } \\
{[28]}\end{array}$ \\
\hline 9. & $\begin{array}{l}\text { Emblica } \\
\text { officinalis }\end{array}$ & Euphorbiaceae & $\begin{array}{l}\text { Analgesic, anti-tussive, antiatherogenic, } \\
\text { adaptogenic; cardio, gastro, nephro and } \\
\text { neuroprotective, chemopreventive, radio } \\
\text { and chemo modulatory and anticancer, } \\
\text { antioxidant, anti-inflammatory, anti-mutagenic, } \\
\text { immunomodulatory. }\end{array}$ & & $\begin{array}{l}\text { Tannins, alkaloids, polyphenols, vitamins, } \\
\text { minerals, Gallic acid, ellagic acid, } \\
\text { emblicanin A \& B, phyllembein, quercetin } \\
\text { and ascorbic acid. }\end{array}$ & $\begin{array}{l}\text { Jeevangi et al } \\
\text { [29] }\end{array}$ \\
\hline 10. & $\begin{array}{l}\text { Macrotyloma } \\
\text { uniflorum }\end{array}$ & Fabaceae & $\begin{array}{l}\text { Treatment of heart conditions, } \\
\text { asthma, bronchitis leucoderma, urinary discharges } \\
\text { and for treatment of kidney stones }\end{array}$ & Rats & $\begin{array}{l}\text { Dolichin A \& B, Pyro glutaminyl glutamine, } \\
\text { Flavonoids. }\end{array}$ & $\begin{array}{l}\text { Kumar et } \\
\text { al.[30] }\end{array}$ \\
\hline 11. & $\begin{array}{l}\text { Mimosa } \\
\text { pudica }\end{array}$ & Leguminosae & $\begin{array}{l}\text { Antidiabetic, antitoxin, antihepato-toxin, antioxidant } \\
\text { and wound healing. }\end{array}$ & Rats & $\begin{array}{l}\text { Terpenoids, flavonoids, glycosides, } \\
\text { alkaloids, quinines, phenols, tannins, } \\
\text { saponins, and coumarins. }\end{array}$ & $\begin{array}{l}\text { Sowmya and } \\
\text { Ananthi [31] }\end{array}$ \\
\hline 12. & $\begin{array}{l}\text { Moringa } \\
\text { oleifera }\end{array}$ & Moringaceae & $\begin{array}{l}\text { Anti-inflammatory, antioxidant, Antimicrobial, } \\
\text { antihyperlipidaemic, Antifertility, anticancer, } \\
\text { antihepatotoxic, Antiulcer. }\end{array}$ & $\begin{array}{l}\text { Wistar } \\
\text { albino rats }\end{array}$ & $\begin{array}{l}\text { Tannins, saponins, carbohydrates, } \\
\text { flavonoids, cardiac glycosides, alkaloids, } \\
\text { steroids and terpenes. }\end{array}$ & $\begin{array}{l}\text { Senecha et al. } \\
{[32]}\end{array}$ \\
\hline 13. & $\begin{array}{l}\text { Nasturtium } \\
\text { officinale }\end{array}$ & Brassicaceae & $\begin{array}{l}\text { Cardioprotective / Hypolipidemic, } \\
\text { ntioxidant, Hepatoprotective, Platelet Aggregating } \\
\text { Effect, Anti-Tuberculosis Activity. }\end{array}$ & Rats & $\begin{array}{l}\text { Phenethyl isothiocyanate, phenyl Propionic } \\
\text { acid nitrite, glucoside. }\end{array}$ & $\begin{array}{l}\text { Bahramikia } \\
\text { and Yazdan- } \\
\text { parast [33] }\end{array}$ \\
\hline 14. & $\begin{array}{l}\text { Phyllanthus } \\
\text { reticulatus }\end{array}$ & Phyllanthaceae & $\begin{array}{l}\text { Antidiabetic activity, Antiplasmodial } \\
\text { activity, hypocholesterolemic activity, antimicrobial } \\
\text { activity, cytotoxic activity, hepatoprotective activity } \\
\text { antinociceptive and anti-hyperglycemic activity, } \\
\text { antioxidant activity. }\end{array}$ & $\begin{array}{l}\text { Albino } \\
\text { rats }\end{array}$ & $\begin{array}{l}\text { Lupeol, lupeol acetate, and stigma sterol, } \\
\text { tannic acid, friedelin, epifriedelinol, betulin, } \\
\text { taraxerone, beta-sitosterol, glochidonol, } \\
\text { octacosanol, taraxeryl acetate and } \\
21 \text {-alpha-hydroxyfriedelan-3-one, } \\
\text { betulinic acid, Coumarin, Ellagic acid. }\end{array}$ & $\begin{array}{l}\text { Maruthappan } \\
\text { and Sakthi } \\
\text { Shree. [34] }\end{array}$ \\
\hline 15. & $\begin{array}{l}\text { Pistacia } \\
\text { lentiscus }\end{array}$ & Anacardiaceae & $\begin{array}{l}\text { Antiatherogenic, antimicrobial and } \\
\text { antimutagenic, antioxidant, antifungal, lipid } \\
\text { lowering, hepatoprotective, anticancer, } \\
\text { anthelmintic,wound healing, hypotensive, } \\
\text { antiarthritic, antigout. }\end{array}$ & $\begin{array}{l}\text { Male } \\
\text { Sprague- } \\
\text { Dawley } \\
\text { rats }\end{array}$ & $\begin{array}{l}\text { Resin, essential oil, gallic acid, } \\
\text { anthocyanins and flavonol glycosides, } \\
\text { nortriterpenoids, a-tocopherol and arabino- } \\
\text { galactan proteins. }\end{array}$ & Soliman [35] \\
\hline 16. & $\begin{array}{l}\text { Prosopis } \\
\text { cineraria }\end{array}$ & Fabaceae & $\begin{array}{l}\text { Analgesic, anthyperlipidemic, antipyretic and } \\
\text { antimicrobial activity. }\end{array}$ & Rabbits & $\begin{array}{l}\text { Flavonoids, alkaloids, diketones, phenolic } \\
\text { contents, free amino acids, patulitrin, } \\
\text { spicigerin, prosogerin A,B,C,D, lipids, } \\
\beta \text {-sitosterol, sugars and vitamins. }\end{array}$ & $\begin{array}{l}\text { Purohit and } \\
\text { Ram [36] }\end{array}$ \\
\hline 17. & $\begin{array}{l}\text { Rhus } \\
\text { coriaria L. }\end{array}$ & Anacardiaceae & $\begin{array}{l}\text { Hepatoprotective, anti-ischemic, antimicrobial, } \\
\text { hypoglycemic and hyperlipidemic. }\end{array}$ & $\begin{array}{l}\text { Male } \\
\text { Wistar } \\
\text { rats }\end{array}$ & $\begin{array}{l}\text { Flavonoids, tannins, xanthons, } \alpha \text {-pinene, } \\
\beta \text {-caryophyllene and cembrene; } \alpha \text {-terpineol, } \\
\text { carvacrol and } \beta \text {-caryophyllene alcohol, } \\
\text { farnesyl acetone, exahydrofarnesylacetone } \\
\text { and aliphatic aldehydes. }\end{array}$ & $\begin{array}{l}\text { Shafiei et al. } \\
{[37]}\end{array}$ \\
\hline 18. & $\begin{array}{l}\text { Sesbania } \\
\text { grandiflora }\end{array}$ & Fabaceae & $\begin{array}{l}\text { Anti-bacterial and anti-fungal, antioxidant, } \\
\text { antiurolithiatic, anticonvulsant and hepato- } \\
\text { protective. }\end{array}$ & & $\begin{array}{l}\text { Tanins, flavonoides, coumarins, steroids, } \\
\text { triterpens, Leucocyanidin and cyanidin, } \\
\text { oleanolic acid and its methyl ester \& } \\
\text { kaemferol-3-rutinoside, Saponin and } \\
\text { Sesbanimide. }\end{array}$ & $\begin{array}{l}\text { Saravanaku- } \\
\text { mar et al. [38] }\end{array}$ \\
\hline 19. & $\begin{array}{l}\text { Solanum } \\
\text { macrocarpon }\end{array}$ & Solanaceae & Anti-oxidant & $\begin{array}{l}\text { Wistar } \\
\text { rats }\end{array}$ & Tannins, flavonoids and alkaloids. & $\begin{array}{l}\text { Dougnon et } \\
\text { al. [39] }\end{array}$ \\
\hline
\end{tabular}




\begin{tabular}{|c|c|c|c|c|c|c|}
\hline 20. & $\begin{array}{l}\text { Sphaeran- } \\
\text { thus indicus }\end{array}$ & Asteraceae & $\begin{array}{l}\text { Hypotensive, anxiolytic, neuroleptic, hypolipidemic, } \\
\text { immunomodulatory, antioxidant, antiinflammatory, } \\
\text { bronchodialatory, antihyperglycemic and hepato } \\
\text { protective }\end{array}$ & $\begin{array}{l}\text { Male } \\
\text { albino } \\
\text { rats }\end{array}$ & $\begin{array}{l}\text { Essential oils, glycosides, eudesmanolides, } \\
\text { sesquiterpenes, phenolic glycosides, } \\
\text { Sesquiterpene lactones, flavonoid, } \\
\text { n-pentacosan, stigmasterol, } \beta \text { - sitosterol, } \\
\text { hentriacontane, } \beta \text {-D-glucoside of } \\
\text { hentriacontane, n-triacontanol }\end{array}$ & $\begin{array}{l}\text { Shetty et al. } \\
{[40]}\end{array}$ \\
\hline 21. & $\begin{array}{l}\text { Withania } \\
\text { coagulans }\end{array}$ & Solanaceae & $\begin{array}{l}\text { Hepatoprotective, antiinflammatory, } \\
\text { antihyperglycaemic, hypolipidaemic, free radical } \\
\text { scavenging, antimicrobial, cardiovascular, nervous } \\
\text { system depressant, immuno modulating, } \\
\text { antitumour and cytotoxic. }\end{array}$ & & $\begin{array}{l}\text { Withanolides, withacoagin, coagulan, } \\
\text { withasomidienone, and withaferin }\end{array}$ & $\begin{array}{l}\text { Hemlatha et al. } \\
{[41]}\end{array}$ \\
\hline 22. & $\begin{array}{l}\text { Ziziphus } \\
\text { oenoplia }\end{array}$ & Rhamnaceae & Anticancer, antimicrobial, antioxidative & $\begin{array}{l}\text { Wistar } \\
\text { albino } \\
\text { rats }\end{array}$ & Zizyphinine (A, B, C, D, E, F and G) & $\begin{array}{l}\text { Eswari et al. } \\
{[42]}\end{array}$ \\
\hline
\end{tabular}

\section{Acknowledgements}

Authors are also thankful to the Head and Coordinator (CAS), Department of Zoology, University of Rajasthan, Jaipur (India) for providing necessary facilities.

\section{Funding}

One of authors is financially supported by the Indian Council of Medical Research (ICMR), New Delhi [grant number 45/36/2012/ BMS/TRM].

\section{References}

1. Reiner Z, Tedeschi RE (2006) Atherosclerosis - a paradox of Eastern European countries. Atherosclerosis 7: 461.

2. Simons LA (2002) Additive effect of plant sterol-ester margarine and cerivastatin in lowering low density lipoprotein cholesterol in primary hypercholesterolemia. American Journal of Cardiology 90: 737-740.

3. Yokozawa T, Ishida A, Cho EJ, Nakagawa T (2003) The effects of Coptidis rhizome extract on a hypercholesterolemic animal model. Phytomedicine 10: $17-22$.

4. Freedman JE (2003) "High-fat diets and cardiovascular disease: are nutritiona supplements useful?" Journal of the American College of Cardiology 41: 1750-1752.

5. Kelly RB (2010) Diet and exercise in the management of hyperlipidemia American Family Physician 81: 1097-1102.

6. (2003) Drugs for Lipid Disorders. Treat Guidel Med Lett 1: 77-82.

7. (1992) National Cholesterol Education Program: highlights of the Report of the Expert Panel on Blood Cholesterol Levels in Children and Adolescents. US Department of Health and Human Services, Public Health Service. National Institutes of Health, National Heart, Lung, and Blood Institute. J Am Osteopath Assoc 92: 380-388.

8. Lipman TH, Hayman LL, Fabian CV, DiFazio DA, Hale PM, et al. (2000) Risk factors for cardiovascular disease in children with type I diabetes. Journal of Nursing Research 49: 160-166.

9. (2001) Executive Summary of The Third Report of The National Cholesterol Education Program (NCEP) Expert Panel on Detection, Evaluation, and Treatment of High Blood Cholesterol in Adults (Adult Treatment Panel III). JAMA 285: 2486-2497.

10. Jain KS, Kulkarni RR, Jain DP (2010) Current drug targets for anti hyperlipidemic therapy. Mini Rev Med Chem 10: 232-262.

11. Amundsen ÅL, Ose L, Nenseter MS, Ntanios FY (2002) lant sterol esterenriched spread lowers plasma total and LDL cholesterol in children with familial hypercholesterolemia. Am J Clin Nut 76: 338-344.

12. Davey SG, Pekkanen J (1992) Should there be a moratorium on the use of cholesterol lowering drugs. BMJ 304: 431-440.
13. Muramatsu K, Fukuyo M (1986) Effect of green Tea catechins on plasma cholesterol level in cholesterol feed rats. J Nutr Sci Vitaminol (Tokyo) 56: 509-520.

14. Cox PA (1990) Ethnopharmacology and the search for new drugs. Ciba Found Symp 154: 47-55.

15. Kim I, Kim JY, Hwang YJ, Hwang KA, Om AS, et al. (2011) The beneficial effects of aged black garlic extract on obesity and hyperlipidemia in rats fed a high-fat diet. J Med Plant Res 5: 3159-3168.

16. Sodimu O, Joseph PK, Augusti KT (1984) Certain biochemical effects of garlic oil on rats maintained on high fat-high cholesterol diet. Experientia 40: 78-80.

17. Kamanna VS, Chandrasekhara N (1982) Effect of garlic (Allium sativum linn) on serum lipoproteins and lipoprotein cholesterol levels in albino rats rendered hypercholesteremic by feeding cholesterol. Lipids 17: 483-488.

18. Movahedian A, Sadeghi H, Ghannadi A, Gharavi M, Azarpajooh S (2006) Hypolipidemic activity of Allium porrum L. in cholesterol-fed rabbits. J Med Food 9: 98-101.

19. Tong LT, Zhong K, Liu L, Guo L, Cao L, et al. (2014) Oat oil lowers the plasma and liver cholesterol concentrations by promoting the excretion of faecal lipids in hypercholesterolemic rats. Food Chem 142: 129-134.

20. Thongoun $P$, Pavadhgul $P$, Bumrungpert $A$, Satitvipawee $P$, Harjani $Y$, et al. (2013) Effect of oat consumption on lipid profiles in hypercholesterolemic adults. J Med Assoc Thai 5: S25-32.

21. Maisaa M AL-Rawi (2007) Efficacy of oat bran (Avena sativa L.) in comparison with atorvastatin in treatment of hypercholesterolemia in albino rat liver. Egyptian J Hospital Med 29: 511- 521.

22. Kamesh V, Sumathi T (2012) Antihypercholesterolemic effect of Bacopa monnieri linn. on high cholesterol diet induced hypercholesterolemia in rats. Asian Pac J Trop Med 5: 949-955.

23. Mitra P, Ghosh T, Mitra PK (2014) Effect of an Isolated Compound (BM-1) from Bacopa Monnieri (L.) Wettst. Leaves on Serum Lipids in Normal and Diabetic Rats. SMU Med J 1: 166-174.

24. Dhulasavant V, Shinde S, Pawar M, Naikwade NS (2011) Antihyperlipidemic activity of Cinnamomum tamala Nees. on high cholesterol diet induced hyperlipidemia. Int J Pharm Life Sci 2: 506-510.

25. Bisht S, Sisodia SS (2011) Assessment of antidiabetic potential of Cinnamomum tamala leaves extract in streptozotocin induced diabetic rats. Indian J Pharmacol 43: 582-585.

26. Zulkhairi HA, Khairunnuur AF, Hafipah MRN, Azrina A, Rasadah MA et al. (2010) An aqueous extract of Citrus mitis possesses antioxidative properties and improves plasma lipid profiles in rat induced with high cholesterol diet. $J$ of Med Plants Res 4: 49-57.

27. Luhure RR, Ghanwat DD, Bidkar JS, Dama GY (2013) Preclinical Evaluation for determination of Antihyperlipidemic potential of Cucumis melo fruit juice in high-cholesterol diet induced Hyperlipidemia in rats. Int J Pharm Bio Sci Res Dev 1: 1-9.

28. Pande S, Platel K, Srinivasan K (2012) Antihypercholesterolaemic influence 
of dietary tender cluster beans (Cyamopsis tetragonoloba) in cholesterol fed rats. Indian J Med Res 135: 401-406.

29. Jeevangi S, Manjunath S, Sakhare PM (2013) A study of Anti-Hyperlipidemia Hypolipedimic and Anti-Atherogenic activity of fruit of Emblica officinalis (amla) in high fat fed albino rats. Int J Med Res Health Sci 2: 70-77

30. KumarDS, Prashanthi G, AvasaralaH, Banji D (2013)Antihypercholesterolemic effect of Macrotyloma uniflorum (Lam.) Verdc (Fabaceae) extract on high-fat diet-induced hypercholesterolemia in Sprague-Dawley rats. J Diet Suppl 10: 116-128.

31. Sowmya A, Ananthi T (2011) Hypolipidemic activity of Mimosa pudica Linn on Butter Induced Hyperlipidemia in Rats. Asian J. Res. Pharm. Sci 1: 123-126.

32. Senecha C, Shama PK, D'Souza UP, Shastry CS (2012) Anticholesteremic and Antilipidemic activity of Stem bark extracts of Moringa oleifera in Diet induced hyperlipidemia model in rats. Int J Pharm Chem Sci 1: 567-574.

33. Bahramikia S, Yazdanparast R (2008) Effect of hydroalcoholic extracts of Nasturtium officinale leaves on lipid profile in high-fat diet rats. J Ethnopharmacol 115: 116-1121.

34. Maruthappan V, Sakthi Shree K (2010) Effects of Phyllanthus reticulatus on lipid profile and oxidative stress in hypercholesterolemic albino rats. Indian $J$ Phar 42: 388-391.

35. Soliman GZA (2012) Effect of Nuts (Pistachio or Almonds) consumption on lipid profile of Hypercholesterolemic rats. Asian J Pharm Clinical Res 5: 4753.
36. Purohit A, Ram H (2012) Effect of Prosopis cineraria bark extract on hematology in hypercholesterolemic rabbits. Indian J Fundamental App Life Sci 2: 96-100.

37. Shafiei M, Nobakht M, Moazzam AA (2011) Lipid-lowering effect of Rhus coriaria L. (sumac) fruit extract in hypercholesterolemic rats. Pharmazie 66: 988-992.

38. Saravanakumar A, Vanitha S, Ganesh M, Jayaprakash J, Ramaswamy NM (2010) Hypolipidemic activity of Sesbania grandiflora in triton wr-1339 induced hyperlipidemic rats. Int J Phytomed 52-58.

39. Dougnon TV, Bankolé HS, JKlotoé JR, Sènou M, Fah L, et al. (2014) Treatment of hypercholesterolemia: screening of Solanum macrocarpon Linn (Solanaceae) as a medicinal plant in Benin. Avicenna J Phytomed 4: 160169.

40. Shetty N, Hegde P, Harini A (2014) Hypocholesterolemic plants. Int Ayur Med J 2: 64 .

41. Hemalatha S, Wahi AK, Singh PN, Chansouria JP (2006) Hypolipidemic activity of aqueous extract of Withania coagulans Dunal in albino rats. Phytother Res 20: 614-617.

42. Eswari ML, Bharathi RV, Jayshree N (2013) Hypolipidemic Activity on Ethanolic Extract of Leaves of Ziziphus oenoplia (L) Mill. Gard. Int J Pharm Bio Archives 4: 136-141

Copyright: (c) 2015 Lakhne R, et al. This is an open-access article distributed under the terms of the Creative Commons Attribution License, which permits unrestricted use, distribution, and reproduction in any medium, provided the original author and source are credited. 